\title{
Assessing gene action for hypoxia tolerance in cotton (Gossypium hirsutum L.) ${ }^{1}$
}

\section{Evaluación de la acción genética para la tolerancia a hipoxia en algodón (Gossypium hirsutum L.)}

\author{
Altaf Hussain ${ }^{2}$, Zafar Ullah Zafar ${ }^{3}$, Habib-ur-Rehman Athar ${ }^{3}$, Jehanzeb Farooq $^{4}$, Saghir Ahmad , Wajad Nazeer $^{6}$ \\ Recibido: 9 de enero, 2018. Aceptado: 26 de junio, 2018. This work was part of PhD research conducted by Altaf Hussain at Cotton Research \\ Institute, Multan, Pakistan. \\ 2 Cotton Research Institute, Old Shujabad Road, Multan 60800, Pakistan. altafhussainazmi@yahoo.com \\ 3 Institute of Pure and Applied Biology, Bahauddin Zakariya University, Multan 60800, Pakistan. drjehanzeb.pbg@gmail.com, habibathar@ \\ bzu.edu.pk \\ 4 Ayub Agricultural Research Institute, Cotton Research Station, Faisalabad, Pakistan. jehanzeb1763@hotmail.com (corresponding author; \\ http://orcid.org/0000-0003-0738-410X). \\ 5 Cotton Research Institute, Multan, Pakistan.saghirahmad_1@yahoo.com \\ 6 Mohammad Nawaz Sharif Agriculture University, Multan, Pakistan. wajidnazirpbg@ gmail.com
}

\begin{abstract}
Introduction. The inheritance studies on hypoxia tolerance in cotton are very scanty. Objective. The objective of this work was to study the inheritance pattern of seed cotton yield, ginning out-turn, and fiber length under normal and hypoxia conditions. Materials and Methods. An $8 \times 8$ diallel mating system was employed in $\mathrm{F}_{1}$ generation of cotton. The experiment was conducted during the years 2011-2012 at Cotton Research Institute, Multan, Pakistan. Results. Analysis of variance revealed significant variation $(\mathrm{P}<0.01)$ for all the traits under both non-stress and flooding stress conditions. The value of regression coefficient $b$ deviated significantly from zero but not from unity for all the traits which enabled further analysis of the data. The additive component (D) was significant for all the traits and this has more values than the values of dominance components $\mathrm{H}_{1}$ and $\mathrm{H}_{2}$, which clearly indicates the preponderance of additive genetic effects. Under normal and hypoxia conditions the estimates of narrow sense heritability were higher. Conclusion. Predominance of additive genetic effects, high heritability along with partial dominance under both conditions suggested that selection for these traits under hypoxic environment at early generation will be useful.
\end{abstract}

Keywords: waterlogging, regression coefficient, diallel, heritability.

\section{Resumen}

Introducción. Los estudios de heredabilidad sobre la tolerancia a la hipoxia en el algodón son muy escasos. Objetivo. El objetivo de este trabajo fue estudiar el patrón de heredabilidad del rendimiento del algodón en semilla, desmote y la longitud de la fibra en condiciones normales e hipoxia. Materiales y métodos. Se empleó un sistema de apareamiento dialélico de 8 × 8 en la generación $\mathrm{F}_{1}$ de algodón. El experimento se realizó durante los años 20112012 en el Cotton Research Institute, Multan, Pakistán. Resultados. El análisis de la varianza reveló una variación significativa $(\mathrm{P}<0.01)$ para todos los rasgos bajo condiciones sin estrés y de estrés por inundación. El valor del coeficiente de regresión b se desvió significativamente de cero, pero no de la unidad para todos los rasgos, lo que permitió un mayor análisis de los datos. El componente aditivo (D) fue significativo para todos los rasgos y tiene más valores que los valores de los componentes de dominancia $\mathrm{H}_{1}$ y $\mathrm{H}_{2}$, lo que indica claramente la preponderancia de los efectos genéticos aditivos. En condiciones normales y de hipoxia, las estimaciones de heredabilidad de sentido 
estrecho fueron mayores. Conclusión. El predominio de los efectos genéticos aditivos, la alta heredabilidad, junto con dominancia parcial bajo ambas condiciones, sugirieron que sera útil la selección de estos rasgos en un ambiente hipóxico en la generación temprana.

Palabras clave: anegamiento, coeficiente de regresión, dialélico, heredabilidad.

\section{Introduction}

All higher plants require water, but excess water in roots can cause injury and can be lethal due to low oxygen diffusion through water coupled with its limited solubility leads to low oxygen availability (Sairam et al., 2008). Cotton (Gossypium hirsutum L.) is a widely studied crop and is the main source of natural fiber worldwide (Riaz et al., 2013); occupies a pivotal position as fiber crop of masses of the world in general and of Pakistan in particular (Imran et al., 2012). Periodic flooding or waterlogged conditions reduces crop yields of cotton in developing countries like Pakistan, India, and China (Pang et al., 2004). The yield penalty resulting from waterlogging may vary between $15 \%$ to $80 \%$, depending on the species, soil type and duration of the stress (Zhou, 2010). Cotton is sensitive to waterlogging which results in young square shedding at reproductive stage which is found to be the result of hormonal imbalance (de-Brito et al., 2013). Waterlogging sensitivity in cotton is linked with photosynthetic inhibition (Najeeb et al., 2015). Plant tolerance to low $\mathrm{O}_{2}$ varies dramatically between species, suggesting the existence of distinct, species-specific molecular mechanisms of plant adaptation to hypoxia (Zhou, 2010). It is, therefore, developing waterlogging tolerant varieties has long been a top priority for plant breeders. The agronomic definition of waterlogging tolerance is the maintenance of relatively high grain yields under waterlogging relative to non-waterlogged conditions (Setter and Waters, 2003). Accordingly, numerous phenotype-based indices have been used both in genetic studies (Parelle et al., 2010) and in breeding programs (Zhou, 2010).

The diallel set of crosses has been widely used by breeders to identify the genetics of more compiled traits and at the same time applied in selecting the parents for utilization in crossing programme for the evolution and development of new variants (Jinks and Hayman, 1953; Dickinson and Jinks, 1956). In order to increase crop productivity in flooded soils, development of flooding-tolerant genotypes/strains/accessions is required. Therefore, the objective of work was to study the inheritance pattern of seed cotton yield, ginning out-turn, and fiber length under normal and hipoxia conditions.

\section{Materials and methods}

\section{Development and assessment of plant material}

The plant material used in present genetic studies was developed by screening on the basis of mortality percentage rate and these were selected after conducting the experiment in the research area of the Department of Agriculture, Cotton Research Institute, Multan, Pakistan; (30 $11 \mathrm{~N}$ and $\left.71^{\circ} 28 \mathrm{E}\right)$ during the years 2011-2012. Eight diverse genotypes/accessions/cultivars of cotton belonging to Gossypium hirsutum L. possessed unique economical and morphological traits. In our previous studies, 60 genotypes/accessions were screened for flooding tolerance, and four flooding tolerant and four flooding sensitive genotypes/accessions were selected at the seedling, flowering, and boll development stages. Of these, MNH-564, FH-114, MNH-786, and CIM-573 were flooding tolerant and N-KRISHMA, LRA-5166, CEDIX and H-142 were flooding sensitive. Brief descriptions of eight genotypes with their peculiar characteristics are enlisted below in Table 1. 
Table 1. Salient economic features with their source of cotton (Gossypium hirsutum L.) accessions / strains / varieties tolerant and sensitive to hypoxia. Department of Agriculture, Cotton Research Institute, Multan, Pakistan, during the years 2011-2012.

Cuadro 1. Características económicas destacadas con su fuente de algodón (Gossypium hirsutum L.) accesiones / cepas / variedades tolerantes y sensibles a la hipoxia. Departamento de Agricultura, Cotton Research Institute, Multan, Pakistán, durante los años 2011-2012.

\begin{tabular}{|c|c|c|c|}
\hline $\begin{array}{l}\text { Tolerant / sensitive } \\
\text { to hypoxia }\end{array}$ & Parents & Source & Peculiar features of parents \\
\hline \multirow{4}{*}{ 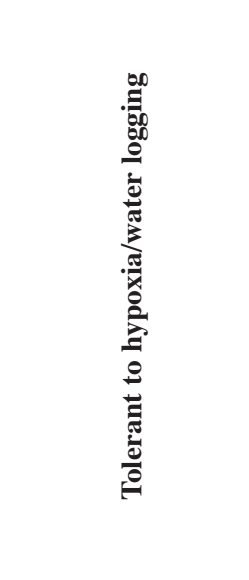 } & MNH-564 & $\begin{array}{l}\text { Cotton Research Station, Multan, Pakistan. } \\
\text { (indigenous). }\end{array}$ & $\begin{array}{l}\text { Med. tolerant to CLCuV, tall statured, spreading, } \\
\text { lush green and med leaves, high GOT \%, med S } \\
\text { length, good fibre strength and fineness with high } \\
\text { yield potential. }\end{array}$ \\
\hline & FH-114 & $\begin{array}{l}\text { Cotton Research Institute, AARI; } \\
\text { Faisalabad, Pakistan. (indigenous). }\end{array}$ & $\begin{array}{l}\text { Med. tolerant to CLCuV, highly response to } \\
\text { inputs, Med. tall, good GOT \%, good micronaire, } \\
\text { fibre strength and uniformity, with early maturing, } \\
\text { profusely hairy green leaves. }\end{array}$ \\
\hline & MNH-786 & $\begin{array}{l}\text { Cotton Research Institute, Multan, } \\
\text { Pakistan. (indigenous). }\end{array}$ & $\begin{array}{l}\text { Tall habit, spreading, lush green, broad leaves } \\
\text { with big boll size and weight, positive response to } \\
\text { inputs, high GOT \% med. S L, good micronaire, } \\
\text { high fibre strength with high yield potential. }\end{array}$ \\
\hline & CIM-573 & $\begin{array}{l}\text { Central Cotton Research Institute, Multan, } \\
\text { Pakistan. (indigenous). }\end{array}$ & $\begin{array}{l}\text { Long fibre, med. GOT } \% \text {, good micronaire fibre } \\
\text { strength, partial tolerant to CLCuV, uniform } \\
\text { maturing with good yield potential. }\end{array}$ \\
\hline \multirow{4}{*}{ 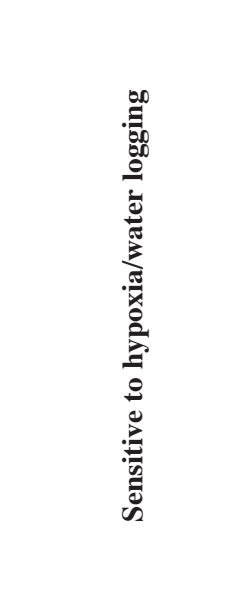 } & N-Krishma & $\begin{array}{l}\text { Nuclear Institute for Agriculture and } \\
\text { Biology, (NIAB), Multan, Pakistan. } \\
\text { (indigenous). }\end{array}$ & $\begin{array}{l}\text { Med. tall statured, med. Leaf with pale green } \\
\text { leaf colour and nectriless, med. GOT }(\%, \text { ) fibre } \\
\text { length and good fibre strength possessed good } \\
\text { yield potential. }\end{array}$ \\
\hline & LRA-5166 & EXOTIC & $\begin{array}{l}\text { Good source of tolerant to CLCuV, med. Statured, } \\
\text { pale green with profusely hairy leaves, bellow } \\
\text { med fibre length and GOT (\%) percentage with } \\
\text { uniform maturity. }\end{array}$ \\
\hline & CEDIX & EXOTIC & $\begin{array}{l}\text { Med. to coarse leaves, med, boll and leave size, } \\
\text { short statured growth habit, bellow med. Staple } \\
\text { length and GOT percentage with average fibre } \\
\text { fineness and strength. }\end{array}$ \\
\hline & H-142 & $\begin{array}{l}\text { Cotton Research Institute, Multan, } \\
\text { Pakistan (indigenous). }\end{array}$ & $\begin{array}{l}\text { Highly responsive to inputs, tall growth habit, } \\
\text { med. Staple length and GOT \%, lush green with } \\
\text { profusely hairy leaves, good fiber traits and early } \\
\text { maturing. }\end{array}$ \\
\hline
\end{tabular}

AARI: Ayub Agricultural Research Institute.

CLCuV: Cotton leaf curl virus / CLCuV: Virus de la curvatura de la hoja de algodón.

GOT: ginning out-turn / GOT: rendimiento de desmote.

The parents were taken from the germplasm maintained source from different research organizations of cotton for experimentation conducted in the field area at Cotton Research Institute Multan, Pakistan during mid May 2011. Before sowing, cotton seeds were dressed/treated with imidacloprid 70 WS @ $10 \mathrm{~g} / \mathrm{kg}$. Eight parents, four tolerant and four sensitive to hypoxia were planted comprising area five meters with three rows of each parent, skipping one row after each parent/strain was spaced planted row to row and plant to plant distances were 75 and $30 \mathrm{~cm}$ respectively. Seedling emergence completed five to seven days after sowing. The first light irrigation was applied just three days after sowing experiment to ensure seed germination. The subsequent irrigations were done by 
keeping in view of agro-climate conditions. The strains/accessions started blooming after 35 to 45 days of sowing varies from strain to strain. Emasculation was done afternoon on the day prior to pollination (all precautionary measures were adopted during emasculation and pollination live out). The eight parents were crossed in all possible combinations following full 8x8 diallel analysis including direct and reciprocal crosses. A large number of crosses were attempted to produce a sufficient quantity of $\mathrm{F}_{0}$ seeds. Some of the buds were also covered with glassine bags to produce self-seeds. At maturity (opened bolls) the crossed as well selfed bolls were picked and seed cotton was ginned to obtained seed cotton (lint) and $\mathrm{F}_{0}$ seeds.

During the next crop season, mid-May 2012 (normal planting season) all possible $\mathrm{F}_{1}$ crosses along with their parents two sets (one set for normal/control and the other one was subjected to hypoxia) were sown in a triplicated randomized complete block design. Each treatment comprised of four meter with a row to row and plant to plant spacing of 75 and $30 \mathrm{~cm}$ respectively. Two seeds per hole were planted manually which later to thinned single and healthy plantlet per hovel was let to grow. All field operations including hoeing, weeding, cultural practices, and irrigation were carried out identically, to minimize experimental error. Plant protection measures were taken against sucking and bollworm pests accordingly. At the time of flowering and boll formation, one set was subjected to hypoxia/waterlogging up to seven days while the clay mud condition was maintained by applying irrigation. At the end of treatment, waterlogged condition was turned over after $14 \mathrm{~d}$; data of five equal and consecutive plants from each cross of control as well as hypoxia were recorded at the time of maturity for seed cotton yield per plant $(\mathrm{g})$, ginning out-turn $(\%)$ and fiber length $(\mathrm{mm})$.

\section{Seed cotton yield $(\mathrm{g})$}

Seed cotton yield from consecutive five plants from each cross was picked in Kraft paper bags of both normal and waterlogged plants. Produce of two picking were used to obtain total seed cotton yield of a concerned cross.

\section{Measuring of ginning out turn (\%)}

Five samples of seed cotton of each cross from normal and under hypoxia were weighed and ginned in single roller ginning machine. Seed cotton (Lint) was weighed and calculated ginning out-turn percentage from the following method.

$$
\text { Ginning out-turn }(\%)=\frac{\text { Total lint weight of seed cotton obtained }}{\text { Total weight of seed cotton yield sample }} \times(100)
$$

\section{Fiber length}

Qualitative trait like fibre length $(\mathrm{mm})$ was measured with the help of HVI (High Volume Instrument, Uster Spectrum-I, USA.) of five samples from each individual cross of twin under hypoxia and control conditions.

\section{Statistical analysis}

The data were analyzed by analysis of variance (ANOVA) following Steel et al. (1997), to establish the level of significance of differences in the plant traits. The characters which showed significant genotypic differences were further analyzed genetically following Hayman (1954a; 1954b). To test the suitability of the data for the 
additive-dominance model a scaling test i.e. joint regression analysis was carried out. According to Hayman (1954a) the regression coefficient must deviate significantly from zero but not from unity for the data to be adequate for additive-dominance model. The information on gene action was obtained by plotting the covariance (Wr) of each array against its variance (Vr). The characters, qualifying both the tests, were fully adequate for the additivedominance model and those qualifying only one test were considered partially adequate (Farooq et al., 2011; Shakeel et al., 2011). The characters, showing full or partial adequacy, were subjected to diallel analysis following Mather and Jinks (1971).

\section{Estimation of genetic components}

Among the genetic components of variation $\left(\mathrm{D}, \mathrm{F}, \mathrm{H}_{1}, \mathrm{H}_{2}, \mathrm{~h}^{2}\right)$; the statistic, D was an estimate of additive effects while $\mathrm{H}_{1}$ and $\mathrm{H}_{2}$ were variations due to dominance effects of genes. F provided an estimate of the relative frequency of dominant to recessive alleles in the parental lines and will be positive when the dominant alleles are more frequent than the recessive alleles. The statistic $\mathrm{h}^{2}$ provided direction of dominance i.e. positive sign shows a dominance of genes with increasing effect at most of the loci and negative sign shows a dominance of genes with decreasing effect. These components were used to compute further information as $\left(\mathrm{H}_{1} / \mathrm{D}\right) 0.5$, mean degree of dominance; $\mathrm{H}_{2} / 4 \mathrm{H}_{1}$, the proportion of genes with positive and negative effects in the parents and [(4DH$) 0.5+\mathrm{F}$ ] / $\left[\left(4 \mathrm{DH}_{1}\right) 0.5-\mathrm{F}\right]$ provides the proportion of dominant and recessive genes in the parents. Narrow sense heritability $\left(h^{2} n . s\right.$.) and broad sense heritability ( $h^{2} b . s$.) were also based on these parameters that reflected the amount of additive and total genetic variation in parents. Heritabilities were rated as low, medium and high following (Stansfield, 1969).

\section{Results}

Analysis of variance for traits like seed cotton yield, GOT\% and fiber length revealed highly significant results. Additive-dominance model for above-mentioned traits and the validity of some of the assumptions underlying the genetic model were tested by joint regression analysis (Table 2). The regression coefficient ' $b$ ' for all the traits under normal and hypoxia conditions departed significantly from zero but not from unity which allowed further analysis of the data.

\section{Estimation of components of variation and graphical representation}

\section{Seed cotton yield under normal and hypoxia conditions}

Estimation of genetic components analysis revealed that environmental variance (E) was non-significant under normal conditions while it had significant effect under hypoxia. Significant values of additive dominance (D), nonadditive components $\left(\mathrm{H}_{1}\right)$ and $\left(\mathrm{H}_{2}\right)$ for both control and hypoxic environments revealed that the additive and nonadditive genetic effects were important for seed cotton yield (Table 3). However, (D) was greater than $\left(\mathrm{H}_{1}\right)$ and $\left(\mathrm{H}_{2}\right)$ hence additive effects were more pronounced than the dominance component. The negative value of $(\mathrm{F})$ for both conditions revealed that absence of dominance under control and hypoxia conditions. Unequal gene frequency was present for all loci also confirmed by the low ratio of $\mathrm{H}_{2} / 4 \mathrm{H}_{1}=0.2076$ and $\mathrm{H}_{2} / 4 \mathrm{H}_{1}=0.1731$ for both conditions. The $\mathrm{h}^{2}$ value was positive but non-significant indicated that the trend of dominance towards parents but effect was non-significant for both conditions. The value of the degree of dominance was less than unity thus exhibiting partial dominance under normal and hypoxia conditions respectively. The estimates of narrow sense heritability were $92 \%$ 
Table 2. Scaling tests for adequacy of additive dominance model for various plant traits in cotton (Gossypium hirsutum L.). Department of Agriculture, Cotton Research Institute, Multan, Pakistan, during the years 2011-2012.

Cuadro 2. Pruebas de escala para la adecuación del modelo de dominancia aditiva para varios rasgos de la planta de algodón (Gossypium hirsutum L.). Departamento de Agricultura, Cotton Research Institute, Multán, Pakistán, durante los años 2011-2012.

\begin{tabular}{|c|c|c|c|c|c|c|}
\hline \multirow{2}{*}{ Traits } & \multicolumn{2}{|c|}{ Regression slope } & \multicolumn{2}{|c|}{ Mean squares } & \multirow{2}{*}{$\begin{array}{c}\text { Adequacy } \\
\text { to Additive } \\
\text { Dominance Model }\end{array}$} & \multirow{2}{*}{$\begin{array}{c}\text { Joint } \\
\text { regression } \\
\text { coefficient }\end{array}$} \\
\hline & $\mathbf{b}_{0}$ & $b_{1}$ & $\mathbf{W r}+\mathbf{V r}$ & Wr-Vr & & \\
\hline Seed cotton yield under normal condition & $7.06 * *$ & $1.007^{\mathrm{NS}}$ & $1991629 * *$ & $56115.6 * *$ & Partially adequate & $\mathrm{b}=0.87 \pm 0.124$ \\
\hline $\begin{array}{l}\text { Seed cotton yield under hypoxia } \\
\text { condition }\end{array}$ & $10.372 *$ & $2.424^{\mathrm{NS}}$ & $47070.1 * *$ & $42844.83^{\text {NS }}$ & Fully adequate & $\mathrm{b}=0.81 \pm 0.08$ \\
\hline Ginning out-turn under normal condition & $8.751 * *$ & $0.359^{\mathrm{NS}}$ & $50.923 * *$ & $3.39 * *$ & Partially adequate & $\mathrm{b}=0.96 \pm 0.11$ \\
\hline $\begin{array}{l}\text { Ginning out-turn under hypoxia } \\
\text { condition }\end{array}$ & $11.656^{* *}$ & $1.021^{\mathrm{NS}}$ & $147.228 * *$ & $5.3155^{* *}$ & Partially adequate & $\mathrm{b}=0.92 \pm 0.08$ \\
\hline Staple length under Normal condition & $4.642 * *$ & $2.192^{\mathrm{NS}}$ & $0.51876^{* *}$ & $0.02^{\mathrm{NS}}$ & Fully adequate & $b=0.68 \pm 0.15$ \\
\hline Staple length under hypoxia condition & $5.839 * *$ & $1.392^{\mathrm{NS}}$ & $0.03745 * *$ & $0.015^{* *}$ & Partially adequate & $\mathrm{b}=0.81 \pm 0.14$ \\
\hline
\end{tabular}

Where $*=\mathrm{P}<0.05$ and values with no star are not-significant / donde $*=\mathrm{P}<0,05$ y valores sin asterisco son no significativos.

Table 3. Estimation of the components of genetic variation of various plant traits in cotton (Gossypium hirsutum L.). Department of Agriculture, Cotton Research Institute, Multan, Pakistan, during the years 2011-2012.

Cuadro 3. Estimación de los componentes de la variación genética de varios rasgos de la planta de algodón (Gossypium hirsutum L.). Departamento de Agricultura, Cotton Research Institute, Multán, Pakistán, durante los años 2011-2012.

\begin{tabular}{|c|c|c|c|c|c|c|}
\hline Genetic components & $\begin{array}{l}\text { Seed cotton } \\
\text { yield (under } \\
\text { normal) }\end{array}$ & $\begin{array}{l}\text { Seed cotton } \\
\text { yield (under } \\
\text { hypoxia) }\end{array}$ & $\begin{array}{c}\text { Ginning out } \\
\text { turn (under } \\
\text { normal) }\end{array}$ & $\begin{array}{c}\text { Ginning out } \\
\text { turn (under } \\
\text { hypoxia) }\end{array}$ & $\begin{array}{c}\text { Staple length } \\
\text { (under } \\
\text { normal) }\end{array}$ & $\begin{array}{l}\text { Staple length } \\
\text { (under } \\
\text { hypoxia) }\end{array}$ \\
\hline $\mathrm{D}$ & $2611.87 \pm 92.57$ & $418.22 \pm 14.43 *$ & $11.237 \pm 0.38^{*}$ & $10.27 \pm 0.47 *$ & $0.60 \pm 0.06^{*}$ & $0.28 \pm 0.015 *$ \\
\hline $\mathrm{H}_{1}$ & $710.65 \pm 212.8^{*}$ & $124.245 \pm 33.17^{*}$ & $4.22 \pm 0.882 *$ & $5.53 \pm 1.08^{*}$ & $0.45 \pm 0.15^{*}$ & $0.14 \pm 0.035^{*}$ \\
\hline $\mathrm{H}_{2}$ & $590.17 \pm 185.14^{*}$ & $86.05 \pm 28.86^{*}$ & $3.05 \pm 0.76^{*}$ & $4.34 \pm 0.94 *$ & $0.42 \pm 0.13 *$ & $0.11 \pm 0.03^{*}$ \\
\hline $\mathrm{F}$ & $-728.21 \pm 218.72 *$ & $-70.02 \pm 34.1 *$ & $6.024 \pm 0.90$ & $5.76 \pm 1.11^{*}$ & $-0.20 \pm 0.15$ & $0.04 \pm 0.03$ \\
\hline$h^{\wedge}{ }^{2}$ & $22.38 \pm 124.16$ & $15.64 \pm 19.35$ & $4.34 \pm 0.51^{*}$ & $2.17 \pm 0.63 *$ & $0.001 \pm 0.089$ & $-0.002 \pm 0.02$ \\
\hline $\mathrm{E}$ & $3.15 \pm 31.46$ & $14.91 \pm 4.90^{*}$ & $0.02 \pm 0.13$ & $0.13 \pm 0.16$ & $0.005 \pm 0.02$ & $0.005 \pm 0.005$ \\
\hline$(\mathrm{H} 1 / \mathrm{D})^{0.5}$ & 0.52 & 0.55 & 0.61 & 0.73 & 0.87 & 0.72 \\
\hline $4 \mathrm{DH}_{1}^{0.5}+\mathrm{F} / 4 \mathrm{DH}_{1}^{0.5}-\mathrm{F}$ & 0.58 & 0.73 & 2.55 & 2.24 & 0.67 & 1.23 \\
\hline $\mathrm{H}_{2} / 4 \mathrm{H}_{1}$ & 0.21 & 0.17 & 0.18 & 0.20 & 0.24 & 0.20 \\
\hline $\mathrm{h}_{(\mathrm{n} . \mathrm{s})}^{2}$ & 0.92 & 0.887 & 0.80 & 0.70 & 0.79 & 0.79 \\
\hline
\end{tabular}

$*=\mathrm{P}<0.05$ and values with no star are not-significant $/ *=\mathrm{P}<0,05$ y valores sin estrella son no significativos.

under normal conditions and $87.8 \%$ under hypoxia also confirmed the presence of additive attitude. It is evident from the graphical analysis (Figure 1) that partial dominance gene action was involved in controlling seed cotton yield under both environments because the regression line intercepts the Wr-axis above the point of origin. All of the genes 


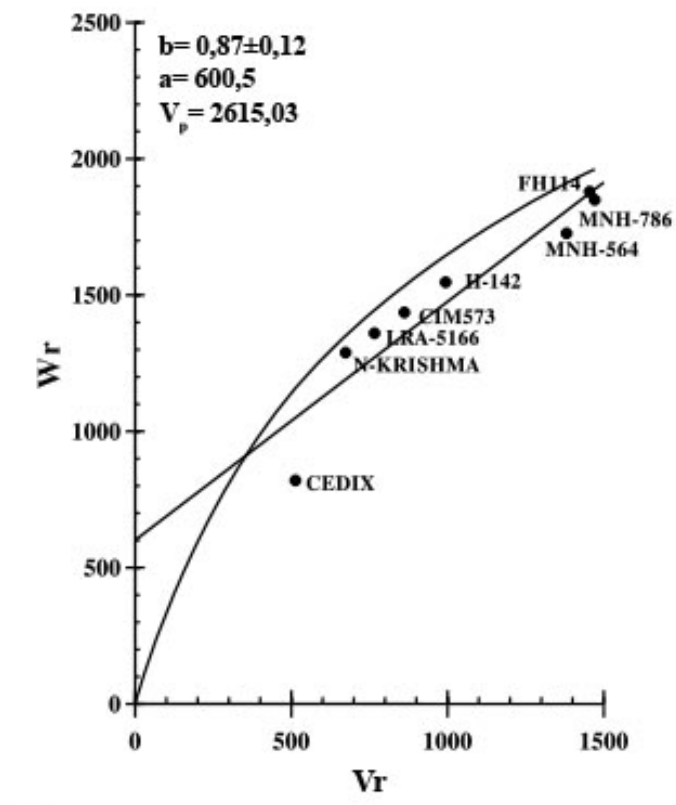

(A)

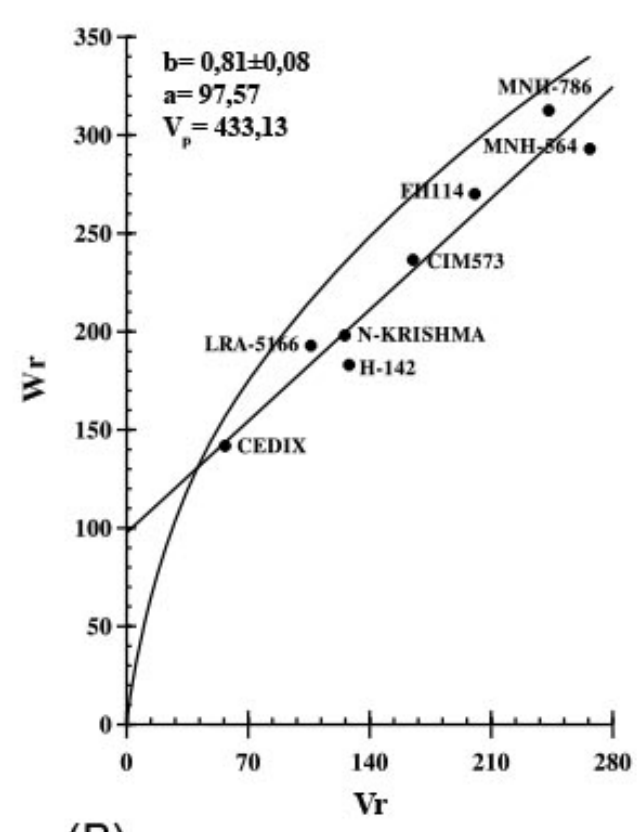

(B)

Figure 1. $\mathrm{Vr} / \mathrm{Wr}$ graph for seed cotton (Gossypium hirsutum L.) yield (g). (A) under control (B) under hypoxia. Department of Agriculture, Cotton Research Institute, Multan, Pakistan, during the years 2011-2012.

Figura 1. Gráfico Vr/Wr para el rendimiento de semilla de algodón (Gossypium hirsutum L.). (g) (A) bajo control (B) bajo hipoxia. Departamento de Agricultura, Cotton Research Institute, Multán, Pakistán, durante los años 2011-2012.

in this trait had an additive genetic effect. Non-allelic interactions were absent as regression line did not deviate from the unit slop. The preponderance of partial dominance in this trait under both conditions revealed that selection will be difficult in segregating generations for seed cotton yield in normal condition (Figure 1A). Gene distribution studies revealed that for control condition, the genotype CEDIX had maximum dominance genes under both environments and on the other hand the FH-114 followed by MNH-786 had maximum recessive genes under normal conditions while MNH-786 followed by MNH-564 had maximum recessive genes under hypoxia (Figure 1B).

\section{Ginning out-turn percentage under normal and hypoxia conditions}

Genetic components analysis revealed that environmental variance (E) was non-significant under normal environment while for hypoxia it had a significant effect. The significance of the additive component (D) indicating the main contribution of additive effects in controlling GOT under both conditions was observed in Table 3. The dominance components $\left(\mathrm{H}_{1}\right)$ and $\left(\mathrm{H}_{2}\right)$ were unequal and less than additive component (D) confirming the important role of additive genes in controlling GOT under both conditions. Like seed cotton yield under normal and hypoxia, the value of $\mathrm{H}_{2} / 4 \mathrm{H}_{1}$ was less than 0.25 , which indicated unequal distribution of genes for this trait among the parents. Similarly, the $(F)$ value was negative which signified the least role of dominant genes under normal conditions while it was positive under hypoxia which signified the important role of dominant genes under hypoxic conditions. The $\mathrm{h}^{2}$ values were positive and significant revealed that trend of dominance towards parents for both environments the value of the degree of dominance was less than one in both environments suggesting the 
occurrence of partial dominance in $\mathrm{F}_{1}$ hybrid which was supported by the regression slope in Figure 2. The estimate of narrow sense heritability was $80 \%$ under normal and $96.7 \%$ under hypoxia conditions.

Under normal conditions the variety FH-114 had maximum number of dominant genes for GOT\% followed by N-KARISHMA and CIM-573 and the genotype LRA-5166 had the maximum recessive genes followed by H-142 and CEDIX (Figure 2B). Under hypoxia the cultivar N-KARISHMA had maximum number of dominant genes followed by MNH-564 and FH-114 and the genotype LRA-5166 had the maximum recessive genes followed by CEDIX and H-142 (Figure 2B).

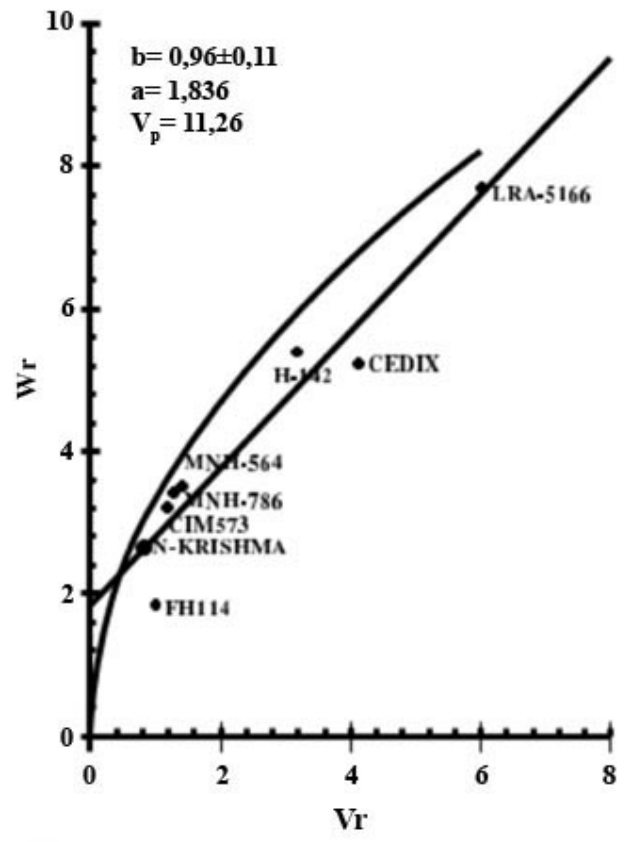

(A)

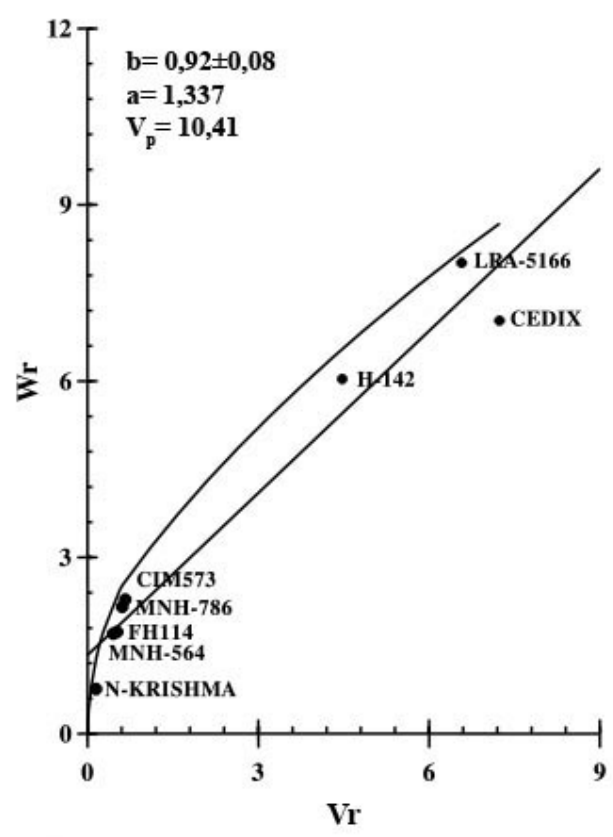

(B)

Figure 2. $\mathrm{Vr} / \mathrm{Wr}$ graph for ginning out-turn (GOT\%) in cotton (Gossypium hirsutum L.). (A) under control (B) under hypoxia. Department of Agriculture, Cotton Research Institute, Multan, Pakistan, during the years 2011-2012.

Figura 2. Gráfico Vr/Wr de rendimiento el desmote (GOT\%) en algodón (Gossypium hirsutum L.). (A) bajo control (B) bajo hipoxia. Departamento de Agricultura, Cotton Research Institute, Multán, Pakistán, durante los años 2011-2012.

\section{Staple length under normal and hypoxia conditions}

The estimation of genetic components of variation for staple length revealed the significance of additive component (D) under both environments indicating the main contribution of additive effects in controlling staple length (Table 3). The dominance components $\left(\mathrm{H}_{1}\right)$ and $\left(\mathrm{H}_{2}\right)$ were unequal and less than additive component (D) confirming the important role of additive genes in controlling staple length under both environments. The value of $\mathrm{H}_{2} / 4 \mathrm{H}_{1}$ was less than 0.25 , which indicated unequal distribution of genes for this trait among the parents. Similarly, the $(\mathrm{F})$ value was negative which signified the least role of dominant genes under normal conditions and it was positive under hypoxia which signified the important role of dominant genes under hypoxia. The value of degree of dominance was less than one suggesting the occurrence of partial dominance in $\mathrm{F}_{1}$ hybrid under both conditions which were supported by the regression slope in Figure 3. The estimate of narrow sense heritability was 79.0\% 

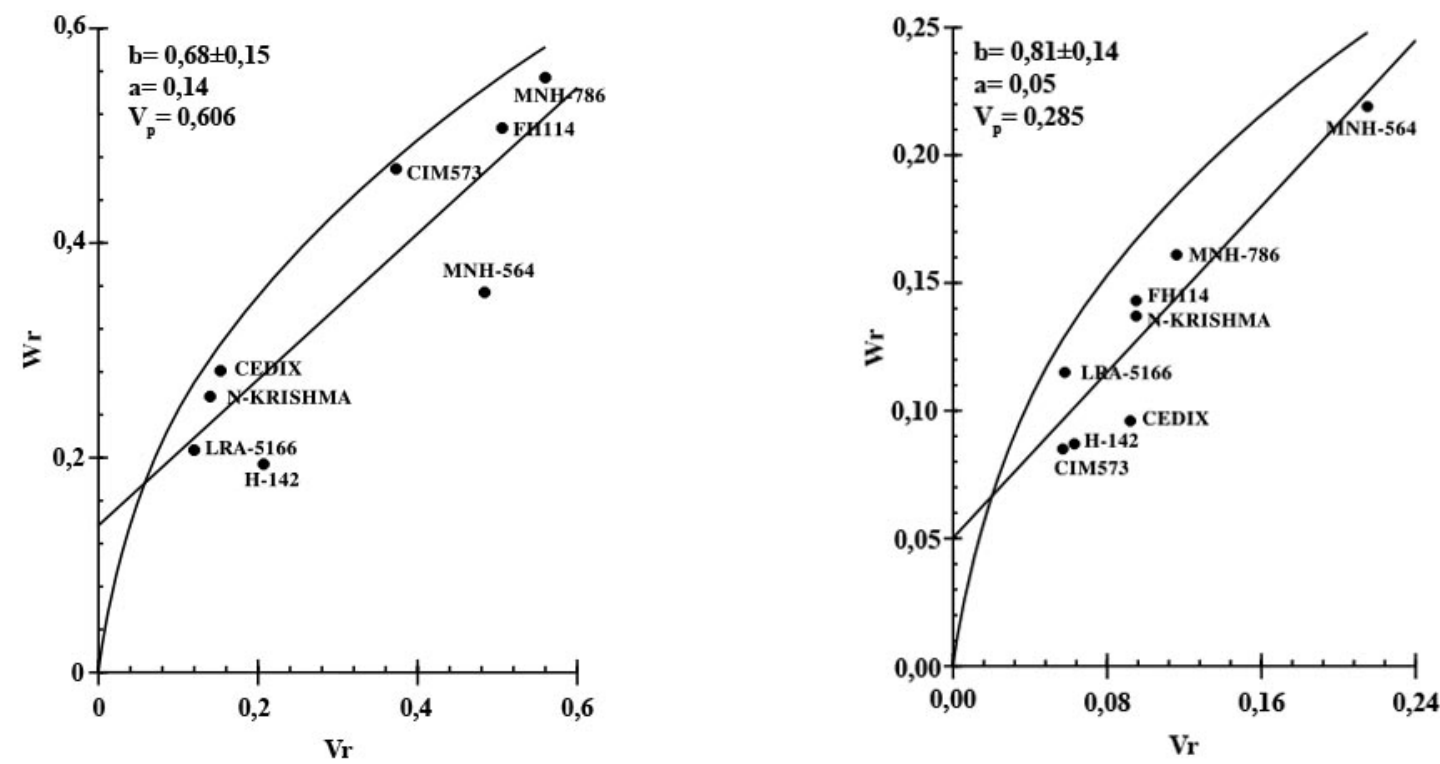

Figure 3. $\quad \mathrm{Vr} / \mathrm{Wr}$ graph for staple length ( $\mathrm{mm}$ ) in cotton (Gossypium hirsutum L.). (A) under control (B) under hypoxia. Department of Agriculture, Cotton Research Institute, Multan, Pakistan, during the years 2011-2012.

Figura 3. Gráfico $\mathrm{Vr} / \mathrm{Wr}$ para longitud de la fibra $(\mathrm{mm})$ de algodón (Gossypium hirsutum L.). (A) bajo control (B) bajo hipoxia. Departamento de Agricultura, Cotton Research Institute, Multán, Pakistán, durante los años 2011-2012.

under normal conditions and 79.2\% under hypoxia environment. Under normal conditions for staple length, the variety H-142 had the maximum number of dominant genes followed by LRA-5166 and N-KARISHMA and the genotype MNH-786 had maximum recessive genes followed by MNH-786 and FH-114 (Figure 3A). While under hypoxia the variety CIM-573 had maximum number of dominant genes followed by H-142 and CEDIX and the genotype MNH-564 had the maximum recessive genes followed by MNH-786 and FH-114 (Figure 3B).

\section{Discussion}

Yield reduction in cotton due to flooding ranging from 10 to 40\% (Hodgson, 1982; Bange et al., 2004). Such yield penalty in cotton due to flooding stress may have been due to changes in various morpho-physiological and biochemical processes. For example, waterlogged conditions caused a reduction in stem elongation, root mass, shoot mass and leaf number in cotton (Klok et al., 2002). In addition, they found altered expression of about 1012 genes in root tissues after flooding in cotton. Similarly, the studies on Arabidopsis, rice and poplar revealed undesirable response to low oxygen involving significant variation in 5-10\% of all the genes assayed (Liu et al., 2005; Kreuzwieser et al., 2009).

\section{Adequacy of additive dominance model}

Two scaling tests in the current studies showed that the additive-dominance model was fully adequate for seed cotton yield under hypoxia and for staple length under controlled conditions. Hussain et al. (2013) reported adequate models for lint percentage, staple length and seed cotton yield under normal conditions. However, Shakeel et al. (2011) reported partial adequate models for seed cotton yield under normal conditions. 


\section{Genetic components}

Additive, dominance and epistasis components play a chief role in the determination of inheritance of the characters under study. The estimation of genetic components of variation revealed that value of additive component (D) was positive and significant found more than the values of dominance components $\left(\mathrm{H}_{1}\right)$ and $\left(\mathrm{H}_{2}\right)$ indicating the important role of additive and non-additive effects in controlling all the characters studied. Khan and Hassan (2011) reported additive effects for ginning out-turn percentage and non-additive effects for seed cotton yield. Moreover, Shakeel et al. (2011) also reported about the contribution of additive effects in $\mathrm{F}_{1}$ generation and non-additive effects in $\mathrm{F}_{2}$ generation for seed cotton yield. Non additive genetic effects have a significant contribution for controlling seed cotton yield (Ali and Khan, 2007; Ali et al., 2008). The value of $\mathrm{H}_{2} / 4 \mathrm{H}_{1}$ was less than 0.25 , which depicted unequal distribution of genes for the trait among the parents for all the traits under normal and hypoxic conditions. Negative F value was observed for staple length under normal and for seed cotton yield under hypoxia signified the unimportant role of dominant genes which are in conformity to the findings of Khan and Hassan (2011), which reported negative $F$ value for lint percentage and seed cotton yield in the $F_{1}$ generation, same researchers reported positive values for these traits while studying $\mathrm{F}_{2}$ generation. The dominance additive ratio represents the degree of dominance. The value of the degree of dominance was less than one for seed cotton yield, ginning out-turn percentage, fiber length, under both conditions in $\mathrm{F}_{1}$ hybrid which was supported by the regression slope in their respective figures. These categories of dominance were suggested in the findings of Falconer and Mackay (1996). According to Turner et al. (1976), epistasis was found for seed cotton yield per plant and ginning out-turn and it was of duplicate type, thus both additive and non-additive effects have been found to be important in cotton. However, the behavior of genes varied for different traits. Singh and Singh (1980) reported additive gene action for seed cotton yield and ginning out-turn. However, Sayal and Sulemani (1996) found over dominance for lint percentage and staple length and additive effects for seed cotton yield. Hussain et al. (2013) reported partial dominance for seed cotton yield and most of the fiber-related traits and Carvalho and De-Carvalho (1995), reported incomplete dominance for fiber percentage which is in accordance with the current findings.

\section{Heritability}

The magnitude of variation that is transmitted from parents to offspring is called as heritability. According to Falconer and Mackay (1996), heritability estimates should be interpreted with great care as it is subjected to significant environmental variations. Plant breeders used heritability for efficiently isolating the extent of genetic variation from the total phenotypic variance. Selection efficiency is dependent upon on genetic variation and extent of heritability (Falconer and Mackay, 1996). The present set of genotypes displayed high genetic variation hence high genetic potential for improvement is available for future breeding programmes. The estimates of heritability were higher for all the studied parameters under normal and hypoxic conditions which are reflecting early generation selection for these traits Shakeel et al. (2011) found higher estimates of heritability while studying $F_{1}$ and $F_{2}$ generation while Khan and Hassan (2011) found higher estimates for seed cotton yield in $F_{1}$ and lower estimates in $F_{2}$ generation. In the findings of Saranga et al. (2004) the higher magnitude of heritability in $\mathrm{F}_{2}$ may be the result of greater genes recombination or low environmental component.

In the present studies, the results of heritability were encouraging for most of the traits so it is assumed that genetic improvement in cotton by selection and breeding can be employed because additive genetic effects mainly affect the genetic mechanism of the traits studied. 


\section{Conclusions}

The additive genetic effects were significant for all the traits under both environments suggested that early generation selection may be followed for these traits. Estimates of narrow sense heritability were also supportive to the addictiveness of the studied traits. The hypoxia tolerant genotypes like MNH-564, FH-114, MNH-786 and CIM-573 and their cross combination can further be exploited in further breeding programs which aimed at the development of varieties possessing hypoxia tolerance.

\section{Acknowledgements}

The authors of this research work are immensely grateful to Dr Farooq Ahmad khan, Associate Professor at University of Agriculture, Faisalabad who assisted us in the preparation of this research publication.

\section{Cited literature}

Ali, M.A., and I.A. Khan 2007. Assessment of genetic variation and inheritance mode of some metric traits in cotton (Gossypium hirsutum L.). J. Agric. Soc. Sci. 3:112-116.

Ali, M.A., I.A. Khan, S.I. Awan, S. Ali, and S. Niaz. 2008. Genetics of fibre quality traits in cotton (Gossypium hirsutum L.). Aust. J. Crop Sci. 2:10-17.

Bange, M., S. Milroy, and P. Thongbai. 2004. Growth and yield of cotton in response to waterlogging. Field Crops Res. 88:129142. doi:10.1016/j.fcr.2003.12.002

Carvalho, L., and L. De-Carvalho. 1995. Genetic control of fibre percentage and boll weight in cotton. Rev. Ceres 42:626-636.

de-Brito, GG, A.C. de-Barcellos-Ferreira, A.L.D.C. Borin, and C. de-Lelis-Morello. 2013. 1-Methylcyclopropene and Aminoethoxyvinylglycine effects on yield components of field-grown cotton. Ciênc. Agrotecnol. 37:9-16. doi:10.1590/ S1413-70542013000100001

Dickinson, A.G., and J.L. Jinks. 1956. A generalised analysis of diallel crosses. Genetics 41:65-78.

Falconer, D., and T. Mackay. 1996. Introduction to quantitative genetics. $4^{\text {th }}$ ed. Longman Group Ltd, Essex, GBR.

Farooq, A., J. Farooq, A. Mahmood, A. Shakeel, A. Rehman, A. Batool, and S. Mehboob. 2011. An overview of cotton leaf curl virus disease $(\mathrm{CLCuD})$ a serious threat to cotton productivity. Aust. J. Crop Sci. 5:1823-1831.

Hayman, B. 1954a. The analysis of variance of diallel tables. Biometrics 10:235-244.

Hayman, B. 1954b. The theory and analysis of diallel crosses. Genetics 39:789-809.

Hodgson. A.S. 1982. The effects of duration, timing and chemical amelioration of short-term waterlogging during furrow irrigation of cotton in a cracking grey clay. Crop Pasture Sci. 33:1019-1028. doi:10.1071/AR9821019

Hussain, S., M. Javed, M. Zubair, and N. Ahmad. 2013. Gene action in the inheritance of agronomic traits ininter varietal diallel crosses of Gossypium hirsutum L. J. Anim. Plant Sci. 23:849-853.

Imran, M., A. Shakeel, F.M. Azhar, J. Farooq, M. Saleem, A. Saeed, and A. Javaid. 2012, Combining ability analysis for withinboll yield components in upland cotton (Gossypium hirsutum L.). Gen. Mol. Res. 11:2790-2800. doi:10.4238/2012. August.24.4 
Jinks, J., and B. Hayman. 1953. The analysis of diallel crosses. Maize GDB 27:48-54.

Khan, N., and G. Hassan. 2011. Genetic effects on morphological and yield traits in cotton (Gossypium hirsutum L.). Span. J. Agric. Res. 9:460-472. doi:10.5424/sjar/20110902-166-10

Klok, E.J., I.W. Wilson, D. Wilson, S.C. Chapman, R.M. Ewing, S.C. Somerville, and E.S. Dennis. 2002. Expression profile analysis of the low-oxygen response in Arabidopsis root cultures. Plant Cell 14:2481-2494. doi:10.1105\%2Ftpc.004747

Kreuzwieser, J., J. Hauberg, K.A. Howell, A. Carroll, H. Rennenberg, A.H. Millar, and J. Whelan. 2009. Differential response of gray poplar leaves and roots underpins stress adaptation during hypoxia. Plant Physiol. 149:461-473. doi:10.1104/pp.108.125989

Liu, F., T. VanToai, L.P. Moy, G. Bock, L.D. Linford, and J. Quackenbush. 2005. Global transcription profiling reveals comprehensive insights intohypoxic response in Arabidopsis.Plant Physiol.137:1115-1129.doi:10.1104\%2Fpp.104.055475

Mather, K., and J.L. Jinks. 1971. Biometrical genetics. $2^{\text {nd }}$ ed. Chapman \& Hall, London, GBR.

Pang, J., M. Zhou, N. Mendham, and S. Shabala. 2004. Growth and physiological responses of six barley genotypes to waterlogging and subsequent recovery. Crop Pasture Sci. 55:895-906. doi:10.1071/AR03097

Najeeb, U., B.J. Atwell, M.P. Bange, and D.K.Y. Tan. 2015. Aminoethoxyvinylglycine (AVG) ameliorates waterlogging-induced damage in cotton by inhibiting ethylene synthesis and sustaining photosynthetic capacity. Plant Growth Reg. 76:83-98. doi:10.1007/s10725-015-0037-y

Parelle, J., E. Dreyer, and O. Brendel. 2010. Genetic variability and determinism of adaptation of plants to soil waterlogging. In: S. Mancuso and S. Shabala, editors, Waterlogging signalling and tolerance in plants. Springer, GER. p. 241-265.

Riaz, M., J. Farooq, G. Sakhawat, A. Mahmood, M.A. Sadiq, and M. Yaseen. 2013. Genotypic variability for root/shoot parameters under water stress in some advanced lines of cotton (Gossypium hirsutum L.). Gen. Mol. Res. 12:552-561. doi:10.4238/2013.February.27.4

Sairam, R., D. Kumutha, K. Ezhilmathi, P. Deshmukh, and G. Srivastava. 2008. Physiology and biochemistry of waterlogging tolerance in plants. Biol. Plantarum 52:401-412. doi:10.1007/s10535-008-0084-6

Saranga, Y., C.X. Jiang, R. Wright, D. Yakir, and A. Paterson. 2004. Genetic dissection of cotton physiological responses to arid conditions and their inter-relationships with productivity. Plant Cell Environ. 27:263-277. doi:10.1111/j.13653040.2003.01134.x

Sayal, O., and M. Sulemani. 1996. Comparison of gene action controlling the qualitative traits in some early maturing cultivars of American cotton (Gossypium hirsutum L). Sar. J. Agric. 12:137-145.

Setter, T. and I. Waters. 2003. Review of prospects for germplasm improvement for waterlogging tolerance in wheat, barley and oats. Plant Soil 253:1-34. doi:10.1023/A:1024573305

Shakeel, A., J. Farooq, M.A. Ali, M. Riaz, A. Farooq, A. Saeed, and M.F. Saleem. 2011. Inheritance pattern of earliness in cotton ('Gossypium hirsutum' L.). Aust. J. Crop Sci. 5:1224-1231.

Singh, D., and R. Singh. 1980. Genetics of ginning characters in Upland cotton. Indian J. Agric. Sci. 50:537-540.

Stansfield, W.D. 1969. Theory and problems of genetics. Schaum's Outline Series. McGraw-Hill Education, NY, USA.

Steel, R.G., J.H. Torrie, and D.A. Dickey. 1997. Principles and procedures of statistics: A biological approach. McGraw-Hill, NY, USA.

Turner, J.H., H.H. Ramey, and S. Worley. 1976. Relationship of yield, seed quality, and fiber properties in Upland cotton. Crop Sci. 16:578-580. doi:10.2135/cropsci1976.0011183X001600040038x

Zhou, M. 2010. Improvement of plant waterlogging tolerance. In: S. Mancuso, and S. Shabala, editors, Waterlogging signalling and tolerance in plants. Springer-Verlag, GER. p. 267-285. 